
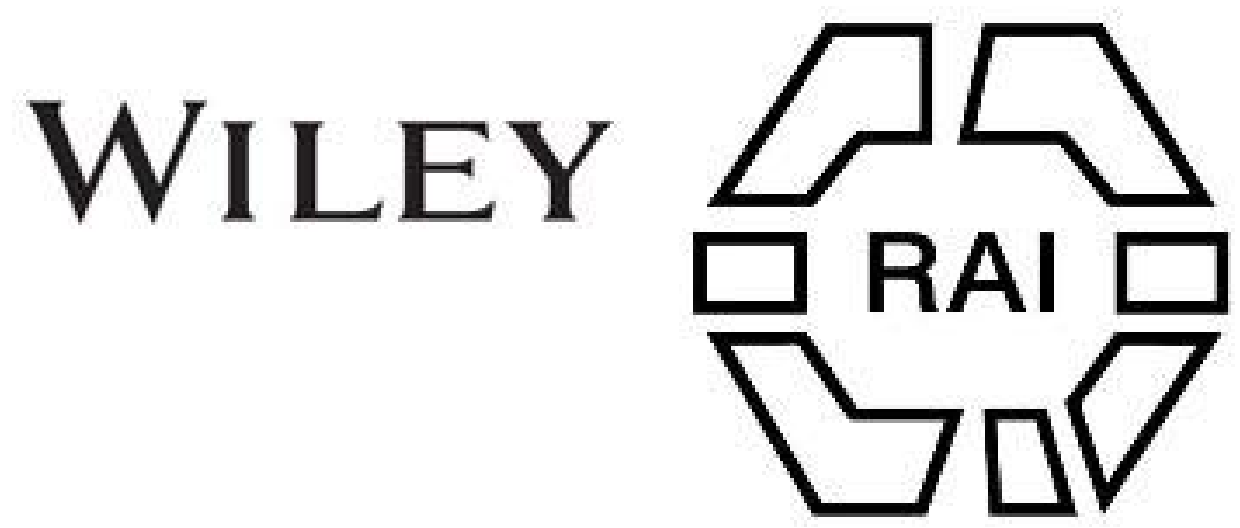

\title{
73. Note on the Antiquities of Sinai.
}

\section{Author(s): R. Campbell Thompson}

Source: Man, Vol. 5 (1905), pp. 131-133

Published by: Royal Anthropological Institute of Great Britain and Ireland Stable URL: http://www.jstor.org/stable/2788001

Accessed: 27-06-2016 08:40 UTC

Your use of the JSTOR archive indicates your acceptance of the Terms \& Conditions of Use, available at

http://about.jstor.org/terms

JSTOR is a not-for-profit service that helps scholars, researchers, and students discover, use, and build upon a wide range of content in a trusted digital archive. We use information technology and tools to increase productivity and facilitate new forms of scholarship. For more information about JSTOR, please contact support@jstor.org.

Wiley, Royal Anthropological Institute of Great Britain and Ireland are collaborating with JSTOR to digitize, preserve and extend access to Man 
to give them courage. Fig. 8 : a design tatued on the back of the wrist, the chains hanging down the hand; supposed to give strength, the fish being a sign of good luck. Figs. 25 and 26 are copied out of the professional tatuer's book of designs, which is an

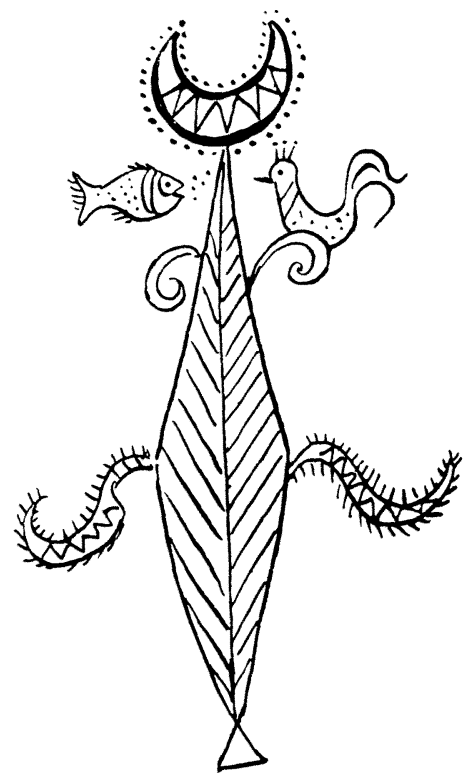

FIG. 25. old French cash column memorandum book (cahier), 8 in. $\times 6 \frac{1}{4}$ in. $(20 \mathrm{~cm} . \times 15 \mathrm{~cm}$.). The designs in this book cover a wide area, nothing appearing to come amiss, as, for instance, the illustration, Fig. 16, which is copied from the trade mark of a Lyons silk manufacturer. There are also sketches of a lamp-

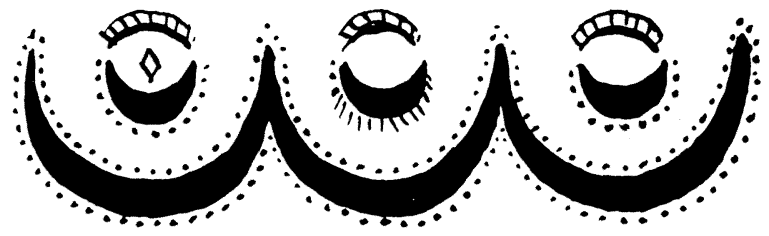

FIG. 26.

post, guns, bicycles, several women, mostly indecent (under European influence), a steam engine, fishes, roses, birds, horsemen, \&c. Against some of these illustrations a price is placed, evidently the cost of tatuing that particular design; thus Fig. 24 costs three francs. Fig. 26 is probably a charm against the evil eye. There is in the designs a great mixture of native and low-class European ideas, and altogether the art as carried out by this professional tatuer was in a low state.

HY. LING ROTH.

Sinai.

Thompson.

Note on the Antiquities of Sinai. By R. Campbell Thompson, M.A.

In his article in the August number of $M_{A N}$ on the Sinaitic temple, Professor 73 Petrie brings forward some criticisms of my remarks in the June number :-

(1.) Professor Petrie corrects my spelling "Sarâbit el-Khadm" to "Serabit el Khādem." The Arabic form, according to Palmer, is given in the Ordnance Survey, Part I., p. 290, as Sarábít el Khádim, both second and third syllables being accented. Professor Petrie himself is inconsistent, as in his letter to the Times of May 23 he spells it "Sarabit el Khadem."

(2.) I mentioned the plans and work which had been done at the temple before my visit, because I thought that the elaborate work of the Ordnance Survey, both topographical and archæological, as well as the careful observations of Lepsius and Bénédite, were worthy of a fuller description than that given in Professor Petrie's letter that " no visitors to this temple had stayed more than a day or two, and scarcely any digging " had been done in the ruins."

(3.) The next objection that Professor Petrie raises is that " the steles in the sbrine " court are not 'much older than the rest,' the earliest steles being the long series in 6. the XII dynasty approach to the temple," but he has not quoted me correctly. What I said was "are for the most part much older than the rest, dating as they do to the “ XII dynasty." On M. Bénédite's plan (published in Maspero's Histoire Ancienne, Vol. I., p. 474) the shrine court is shown to contain ten stelæ, all of this date, wbile the long series in the XII dynasty approach, according to the same authority, contains only eight of the XII dyuasty. The other stelæ are of much later date.

(4.) Professor Petrie objects to my description of the temple as "merely a little [ 131 ] 
" provincial Egyptian shrine." I think it will be admitted, however, that " provincial" is quite a fitting term to be applied to Sinai, and if a comparison be made with the size of the temples at Abydos, Dendera, Edfu, Thebes, \&c., "little" is the proper description for a building only 250 feet long and very narrow.

(5.) Professor Petrie says that "the numerous Bethel stones in the neighbourhood " are some of them inscribed by Egyptians, who adopted the local worship. No such " system of stone records of visits are (sic) known in Egypt, no one familiar with " Egyptian works could write that they "are ordinary Egyptian monumental tablets " of Egyptian type." With regard to records of miners' visits, I think a fair comparison may be made with the inscriptions of Wadi Hammanat. Kings and governors constautly recorded their visits to various places on neighbouring rocks, \&c., as at Konosso, Sehel, and elsewhere in Nubia, at the Nahr el-Kelb in Syria, \&c. As to the stelæ, inscribed and uninscribed, I must still adhere to my view that they are ordinary Egyptian stelæ, and I think the XII dynasty stelæ exhibited in the British Museum will confirm the opinion of anyone interested.

(6.) Professor Petrie says, "more strange is it to read of the Babylonian temples, " which were founded by Sumerians, as being Semitic." When it is remembered that the Semites had begun to obtain a footbold in Babylonia as far back as 3800 B.c., and for several hundreds of years before the fall of Babylon held entire sway over the land, direct Sumerian influence having long disappeared, and when we consider that the Assyrian and Semitic Babylonian rulers, particularly during the later periods, extensively restored and rebuilt the old temples, we see that "Semitic" is the only word which properly describes them. From the fact that Professor Petrie no longer repeats his claim that the Sinaitic temple is the only Semitic temple preserved to us, I infer he tacitly admits the Semitic origin of the temples of Assyria proper which I mentioned.

As regards the challenge that I should state what points of distinctively Semitic rites can be traced in Babylonian temples, I must refer Professor Petrie to the long chapter in Jastrow's Religion on the Temples and the Cult (pp. 612-689), where he will find much interesting matter on the point.

(7.) As regards the slag heaps and the bed of ashes, Lepsius was my authority for the existence of this slag (Letters from Egypt, p. 348). He thought he saw slag there, and measured the heaps, and thought they were remains of the smelting, as I quoted in my article.* But, even if we concede that there is no slag within six miles, Professor Petrie, in his letter to the Times, admits that smelters formed part of the ancient expeditions to the temple, and it certainly is a significant fact that no bones at all were found in the ashes. After all, even supposing that no copper smelting or casting went on, there are a good many uses to which fire may be put besides sacrifice, when there are from fifty to one hundred men living near.

(8.) As regards Professor Petrie's objection to the description given under my photograph of the mines, I think I need say no more than that it was taken from the mined slope of Wadi Maghâra, not far from one of the tunnels.

Finally, in the main body of his article Professor Petrie bases his theory that the temple gives an insight into early Semitic worship on three points : (1) the existence of tanks and basins in the temple, proving " how important the ceremonial of ablution " was in the worship here"; (2) the bed of ashes (without bones), proving the existence of a system of burnt offerings ; (3) "the Bethel system, of oracular dreams and memorial " stones, as in the story of Jacob," and the so-called pilgrim chambers.

* On this point compare Baedeker's Guide to Palestine and Syria (1904), p. 182: "Auf der

"Hochfläche standen Schmelzöfen und das Heiligtum, in welchem sich die knappschaft bei ibren "Festen versammelte." 
With regard to (1), when it is considered that no well has been found in the temple, and, as Professor Petrie justly remarks in his letter, the plateau "is beyond the reach of " camel transport for water," we may presume that "ceremonial ablutions" is not the easiest explanation for the existence of water-tanks in a building that was doubtless as much a place of defence as of worship, as its name, "the heights of the fortress," implies. Any comparison between the hanafiyeh court of Moslem mosques and the courts of this temple must necessarily be precarious, when the composite and borrowed character of Mohammedan buildings (at least 2,000 years later than this temple) is remembered.

With the second point $I$ have already dealt. With regard to the third I do not see how pillars, whether natural or wrought, can be referred especially to an ancient Semitic origin, when nothing in the inscriptions or workmanship has been adduced in proof of this Semitic origin. As regards the pilgrim cubicles, they can as well be explained as dwellings for the 50 to 100 Egyptians, who we know went there, as for the pilgrims of whom we have no knowledge.

R. CAMPBELL THOMPSON.

England: Archæology.

Windle. An Excavation in Kemerton Camp, Bredon Hill. By Bertram C. 74
A. Windle, D.Sc., F.R.S., F.S.A.

Bredon Hill, partly in Worcestershire and partly in Gloucestershire, possesses two earthworks : a smaller, known as Conderton Camp, and a larger, Kemerton Camp-the subject of this note. This camp is entirely in Gloucestershire; in fact, a part of its circumference forms the boundary of a promontory of that county which projects into Worcestershire. As will be seen from the plan (Fig. 1), this camp belongs to the group

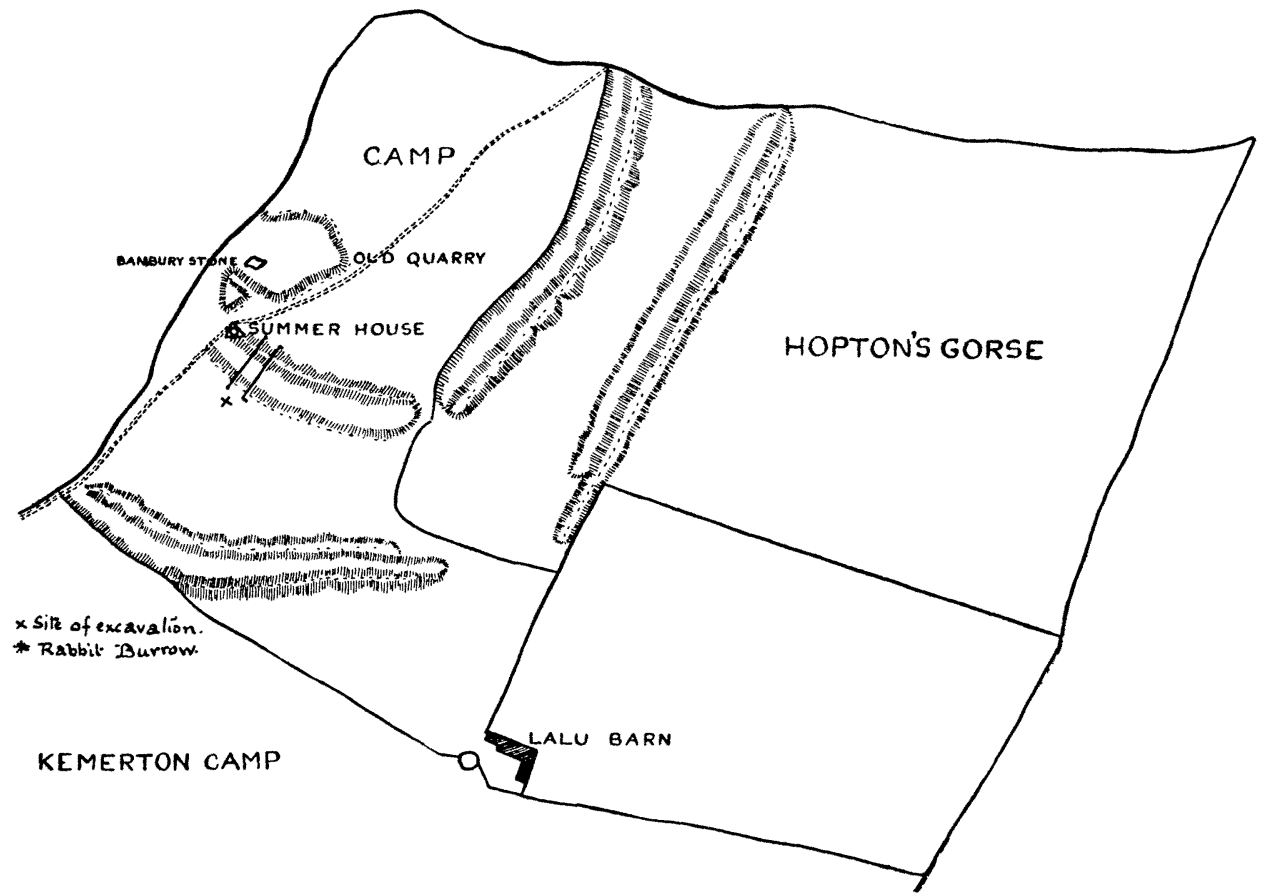

FIG. 1.-PLAN OF CAMP.

of promontory forts, since there are no artificial earthworks to the north and west where the escarpment of the hill is exceedingly steep. The camp contains, in a deep hollow to its south-west corner, a large mass of oolite, known as the Bambury Stone, concerning which many ingenious theories have been spun. It does not seem to be possible 